\title{
Natural regeneration of trees in selectively logged forest in western Amazonia
}

\author{
Anelena Lima de Carvalho ${ }^{\mathrm{a}, *}$, Marcus Vinício Neves d’Oliveira ${ }^{\mathrm{b}}$, Francis E. Putz ${ }^{\mathrm{c}}$, Luís Claudio de Oliveira ${ }^{\mathrm{b}}$ \\ ${ }^{a}$ Tropical Forest Science, National Institute for Amazon Research, Amazonas, Brazil \\ ${ }^{\mathrm{b}}$ EMBRAPA - CPAF-ACRE, Caixa Postal 392, CEP 69900-180 Rio Branco, Brazil \\ ' Department of Biology, University of Florida, Gainesville, FL 32611-8526, USA
}

\section{A R T I C L E I N F O}

\section{Article history:}

Received 30 November 2016

Accepted 27 February 2017

Available online 9 March 2017

\section{Keywords:}

Amazon

Reduced-impact logging

Tropical forestry

Natural forest management

Forest dynamics

Soil compaction

Forest degradation

\begin{abstract}
A B S T R A C T
We evaluated the impacts of selective logging on tree regeneration one, four, and eight years after harvests in Antimary State Forest in the State of Acre, Brazil. We inventoried tree seedlings, saplings, and poles ( $>50 \mathrm{~cm}$ tall to $<10 \mathrm{~cm}$ DBH) on secondary roads, log landing, and skid trails, as well as in the bole and crown zones of canopy gaps created by felling; for comparison we also sampled areas not affected directly by logging. We compared these habitats on the basis soil (physical) characteristics, canopy cover, and floristic composition. For areas one and four years after logging, we supplemented the ground-based information with aerial LiDAR data. By eight years post-logging the size class distributions of tree regeneration in all habitat types resembled those in unlogged areas, and densities were only lower in crown gaps. Eight years after logging, relative densities of pioneer trees were highest on secondary roads and log landings; no among habitat differences were observed in the relative densities of non-pioneer species at any time along the chronosequence. Tree species diversity (Fisher's alpha) converged on unlogged values on skid trails, bole gaps, and crown gaps at 8-years post-logging, but values remained lower on secondary roads and log landings. Canopy openness was greatest one year after logging, especially in log landings (mean $45.4 \pm$ SE $4.5 \%$ ) whereas four and eight years post-logging it did not exceed $10 \%$ and no differences were found among habitats. Soil bulk density was elevated relative to un-logged areas only on log landings one and four years after logging, and this difference disappeared by eight years postlogging. The total area disturbed by logging varied from $7.0 \%$ to $8.6 \%$ with nearly half of the totals in felling gaps (3.0-3.7\%).
\end{abstract}

(c) 2017 Elsevier B.V. All rights reserved.

\section{Introduction}

A challenge for sustainable tropical forest management (SFM) is to secure sufficient regeneration of commercial timber species after selective logging, especially those that are light-demanding (e.g., Fredericksen and Pariona, 2002). Most felling gaps opened by the harvest of single trees are too small for the establishment and growth of many shade-intolerant species (Yamamoto, 2000; Fredericksen and Mostacedo, 2000), which sometimes regenerate more abundantly on log landings and skid trails (e.g., Soriano et al., 2012). Unfortunately, for forest managers, seedlings that do get established in areas previously traversed by heavy equipment can later be inhibited by soil compaction and soil surface displacement (Pinard et al., 1995). Logging may also favor the colonization

\footnotetext{
* Corresponding author at: EMBRAPA - CPAF-ACRE, Caixa Postal 392, CEP 69900180 Rio Branco, Brazil.

E-mail address: anelenacarvalho@gmail.com (A.L. de Carvalho).
}

and growth of non-commercial species that suppress the regeneration of timber trees (e.g., Vieira, 1995; Mostacedo and Fredericksen, 1999). To understand the impacts of selective logging, it is important to know the extent and degree of canopy opening and soil damage, how these disturbances affect tree regeneration, and for how long their impacts persist.

Logging disturbances vary in spatial scale and intensity, from extensive and heavy, such as roads and log landings, to those that are restricted and relatively light, such as skid trails and felling gaps (Karsten et al., 2014). The amounts of soil disturbance and residual tree damage also vary with harvest intensity, log extraction machinery employed, and the extent to which reducedimpact logging (RIL) techniques are employed (Putz et al., 2001). Selective logging also causes other short and long-term effects including changes in forest understory micro-climates, nutrient cycle disruption, and changes in species composition (e.g., Mostacedo et al., 2009; TerSteege et al., 1995; Elliott and Knoepp, 2005; McNabb et al., 1997; Fredericksen and Mostacedo, 2000; 
Pinard et al., 1995). Wide variation in logging intensities $\left(<1 \mathrm{~m}^{3} /\right.$ ha to $>100 \mathrm{~m}^{3} /$ ha), timber extraction methods, and post-logging silvicultural treatments limit generalizations about the effects of logging over time (Putz et al., 2001).

Concepts of SFM vary (e.g., Wang, 2004; Zimmerman and Kormos, 2012; d'Oliveira et al., 2012) as do the silvicultural practices that are appropriate for different forests and management goals. Despite this diversity of conditions and expectations, Brazilian forest law prescribes the same silvicultural system for all its Amazonian forests. This system sets the minimum harvest cycle length at 10 years for low intensity logging $\left(<10 \mathrm{~m}^{3} \mathrm{ha}^{-1}\right)$ and 25-35 years for higher intensity logging $\left(10-30 \mathrm{~m}^{3} \mathrm{ha}^{-1}\right.$; CONAMA, 2009). It seems likely that these rules are not equally appropriate across even the small State of Acre in the western Amazon where the 18 described forest types range from open palm forest to dense forest (Salimon et al., 2011). Locally tailored silvicultural guidelines are especially critical for the hard-to-manage bamboo-dominated forests that cover approximately $161,500 \mathrm{~km}^{2}$ in the departments of Madre de Dios - Peru, Acre Brazil, and Pando - Bolivia (Nelson, 1994; de Carvalho et al., 2013). Design of these guidelines is hampered by the paucity of research on this forest type, especially about natural regeneration of commercial tree species after logging (but see Rockwell et al., 2014; d'Oliveira et al., 2012; d'Oliveira et al., 2006).

We studied tree regeneration dynamics in response to canopy and soil disturbances caused by selective logging in Antimary State Forest in Acre, Brazil. To explore the impacts of logging over time we used a chronosequence of stands logged one, four, and eight years prior to measurement. We compare soil conditions and tree regeneration on abandoned secondary roads, log landings, skid trails, and felling gaps with adjacent areas that were unlogged.

\section{Material and methods}

\subsection{Study site}

Antimary State Forest (ASF) is located between the cities of Rio Branco and Sena Madureira in the State of Acre in the southwest- ern Brazilian Amazon (Fig. 1). ASF covers an area of $768 \mathrm{~km}^{2}$ and has approximately 380 inhabitants (109 families) who make their living through rubber tapping, Brazil-nut collecting, and shifting cultivation. The three dominant vegetation types are dense forests with a uniformly closed canopy and emergent trees, open forest with abundant lianas and palms, and bamboo-dominated forest (tabocal). The climate is classified as Awi (Köppen), with annual precipitation of approximately $2000 \mathrm{~mm} \mathrm{yr}^{-1}$ and a JuneSeptember dry season during which monthly precipitation is $<100 \mathrm{~mm}$; the average temperature is $25^{\circ} \mathrm{C}$. The topography is gently sloping, with an altitudinal range of approximately $300 \mathrm{~m}$; the predominant soils are dystrophic yellow latosols with high clay content (Funtac, 1989).

Formal forest management in the area started in 1985 with establishment of a large research program coordinated by FUNTAC (Acre State Technological Foundation). Between 1999 and 2003, timber was harvested by FUNTAC but in 2004, a forest concession system was adopted through which ASF inhabitants receive social and financial benefits (d'Oliveira et al., 2013).

Two of the Annual Production Units (APUs) we studied were selectively logged following the Modeflora methodology (Figueiredo, 2007) one year (in 2013) and four years (in 2010) prior to our study; the 8-year APU (logged in 2007) was selectively logged following a detailed harvest plan. With the Modeflora approach to selective logging, trees $>35 \mathrm{~cm}$ DBH of commercial species with boles suitable for harvest are tagged, mapped with a high-sensitivity GPS, identified to species, and measured during the forest inventory. Permanent preservation areas and restricted access areas (slopes $>15 \%$ ) are demarcated in the field. Mapped trees are classified as loggable (commercial species $>50 \mathrm{~cm} \mathrm{DBH}$ ), future crop trees (35-50 cm DBH), seed trees ( $10 \%$ of trees of commercial species $>50 \mathrm{~cm} \mathrm{DBH}$ ), and protected species (Bertholetia excelsa and Hevea braziliensis). This information is included on digital forest exploitation plans that are available to all logging crews (Figueiredo, 2007). Adherence to the logging guidelines reportedly reduces the area affected directly by logging from $22.2 \%$ to $14.8 \%$ (EMBRAPA, 2008). The numbers of species harvested and logging intensities in the three APUs in our chronosequence were all similar (Table 1).

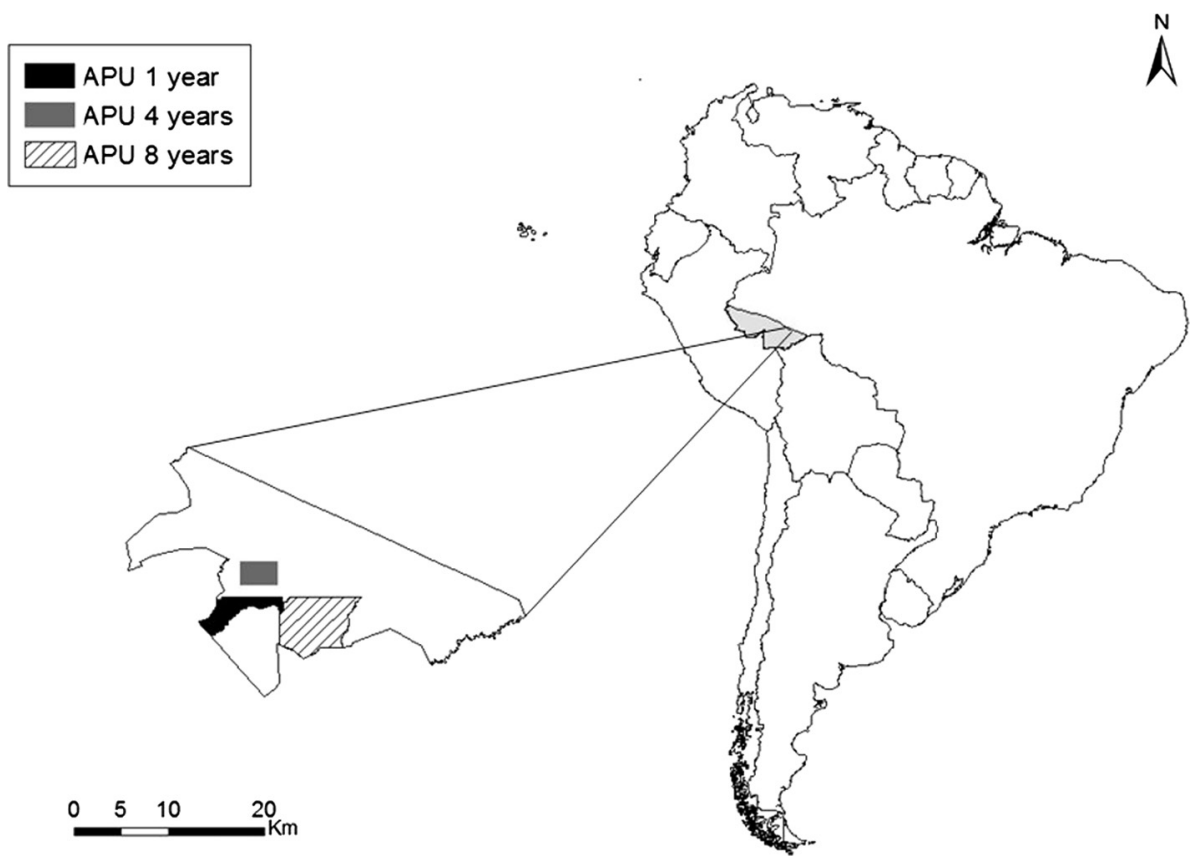

Fig. 1. Antimary State Forest in Acre State, Brazil. 
Table 1

Logging intensity in each annual production unit (APU) in tAntimary State Forest logged in 2007, 2010, and 2013, 8, 4, and 1 year prior to our study, respectively.

\begin{tabular}{|c|c|c|c|c|}
\hline Years after logging & Volume $\left(\mathrm{m}^{3} \mathrm{ha}^{-1}\right)$ & \# Commercial tree species & \# Trees/ha & Effective management area (ha) \\
\hline 1 year & 11.6 & 45 & 1.6 & 632 \\
\hline 4 years & 13.3 & 52 & 1.9 & 380 \\
\hline 8 years & 10.5 & 56 & 1.5 & 1509 \\
\hline
\end{tabular}

\subsection{Sampling}

We sampled natural regeneration (trees $>50 \mathrm{~cm}$ tall and $<10 \mathrm{~cm}$ $\mathrm{DBH}$ ) in 10 randomly located plots in each of five studied habitats in each of the three APUs: bole zones of felling gaps; crown zones of felling gaps; skid trails; secondary roads; and, log landings (Fig. 2). Soil bulk density was measured on skid trails and log landings. We also sampled soils and tree regeneration in control plots located $50-200 \mathrm{~m}$ from any logging infrastructure. Plots on log landings were $10 \mathrm{~m} \times 10 \mathrm{~m}, 10 \mathrm{~m} \times 15 \mathrm{~m}$ or $15 \mathrm{~m} \times 15 \mathrm{~m}$ depending on landing size $\left(400-500 \mathrm{~m}^{2}\right)$; secondary road and skid trail plots were $3 \mathrm{~m} \times 40 \mathrm{~m}$; bole zone plots were $2 \mathrm{~m} \times 10 \mathrm{~m}$ to $2 \mathrm{~m} \times 25 \mathrm{~m}$ depending on the felled tree's height; crown zone plots varied from $5 \mathrm{~m} \times 10 \mathrm{~m}$ to $10 \mathrm{~m} \times 15 \mathrm{~m}$ depending on the size of crown of the felled tree; and, plots in unlogged areas were $3 \mathrm{~m} \times 20 \mathrm{~m}$.

\subsection{Natural regeneration}

Natural regeneration, included all tree species found in the logged and control areas, described in terms of density and species diversity. The plants were divided into seedlings $\geq 50 \mathrm{~cm}$ and $\leq 1 \mathrm{~m}$ tall, small saplings $>1 \mathrm{~m}$ and $\leq 3 \mathrm{~m}$ tall, large saplings $>3 \mathrm{~m}$ and $\leq 5 \mathrm{~cm} \mathrm{DBH}$, and, poles $5-10 \mathrm{~cm} \mathrm{DBH}$. Species diversity is expressed as Fisher's alpha (Magurran, 2004) calculated with EstimateS (Version 9, R. K. Colwell, 2013). The relative densities of pioneer and non-pioneer species were used to explore differences among and the disturbed habitats and between the logged and unlogged areas. Classification of tree species as pioneer or nonpioneer (sensu Swaine and Withimore, 1988) was based on the literature (Tables S1 and S2).

\subsection{Environmental conditions}

Soil samples were collected from $0.5 \times 0.5 \times 0.5 \mathrm{~m}$ trenches dug in log landings, skid trails, and unlogged sites. To preserve their structure, the samples were collected with metal rings $(54 \times 50 \mathrm{~mm})$ at depths of $2.5-7.5 \mathrm{~cm}, 12.5-17.5 \mathrm{~cm}$, and $32.5-$ $37.5 \mathrm{~cm}$. From soil samples with preserved structure, bulk density was determined with the volumetric ring (Blake and Hartge, 1986) and volumetric flask methods (EMBRAPA, 1997). To describe canopy openness, hemispherical photographs were taken at the center of plots at $1.3 \mathrm{~m}$ above the ground with an automatic optical canopy analyzer (CI-110, CID Bio-Science) and processed with Gap Light Analyzer version 2.0.

\subsection{Estimate of the area directly affected by logging}

The areas directly affected by logging (i.e., secondary roads, log landings, skid trails, and felling gaps were measured with LiDAR. We generated a vegetation relative density model (RDM) and a digital canopy model (DCM) with $1 \mathrm{~m}$ resolution using the FUSION package (McGaughey, 2010) following the method suggested by d'Oliveira et al. (2012).

\subsection{Statistical analyses}

Tree density, floristic composition, canopy openness, and soil bulk density were compared among habitats and by years after logging with two-way analysis of variance using R software (Development Core Team, 2008). To evaluate compositional changes with time-since-logging, species presence or absence data from each plot were ordinated with non-metric multidimensional scaling

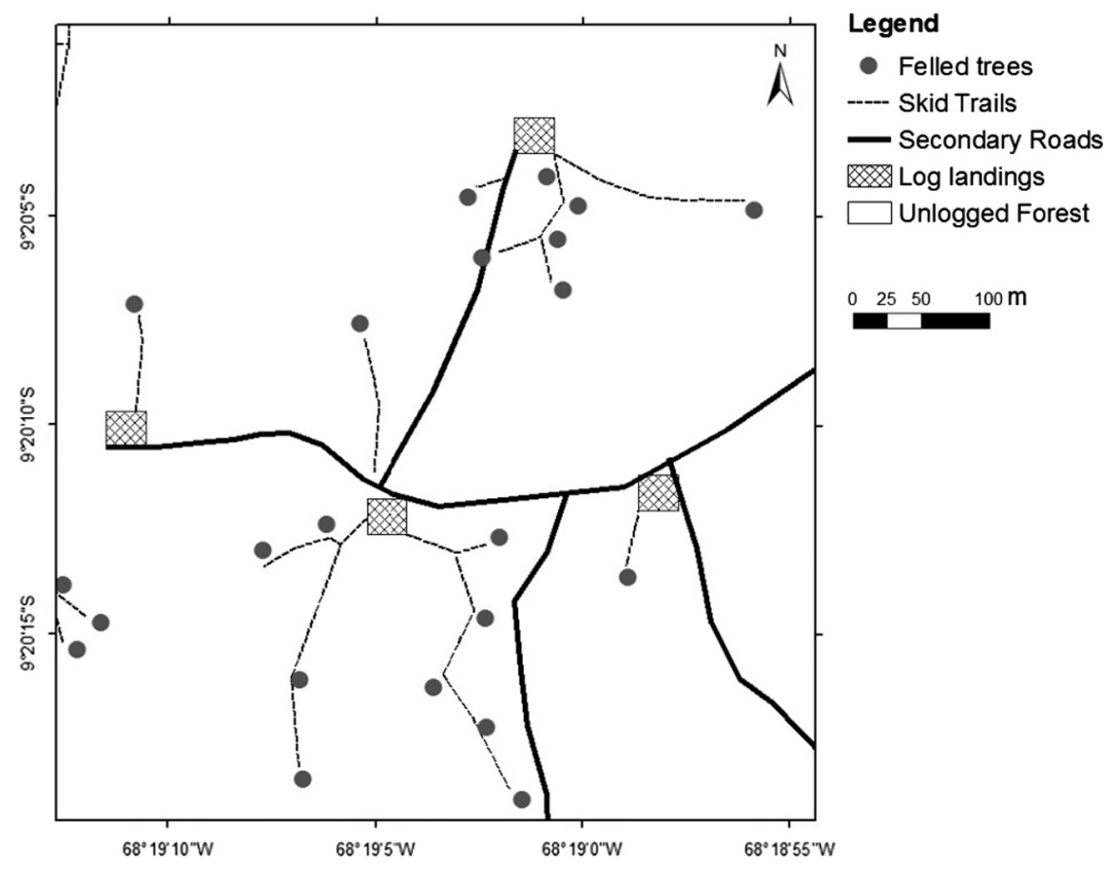

Fig. 2. Illustration of the studied habitats. 
(NMDS) based on Bray-Curtis dissimilarity coefficients and then subjected to PERMANOVA implemented with $\mathrm{R}$ version 3.0.1 ( $\mathrm{R}$ Development Core Team, 2011) and the Vegan Package (Oksanen et al., 2013).

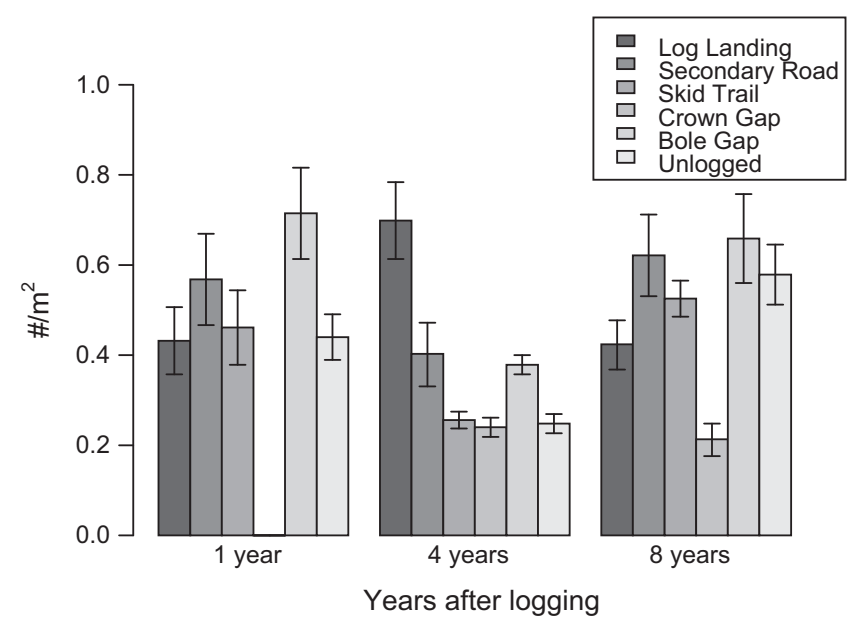

Fig. 3. Overall densities of tree seedlings, saplings, and poles $\left(\# / \mathrm{m}^{2}\right.$; mean $\left.\pm 1 \mathrm{SE}\right)$ on log landings, secondary roads, skid trails, felling gaps (bole and crown zones sampled separately), and unlogged forest 1,4 , and 8 years after selective timber harvests.

\section{Results}

\subsection{Natural regeneration}

Based on 5937 seedlings in 146 plots, natural regeneration density differed with time-since-logging $(p<0.001)$ and among habitats $(p<0.001$; Fig. 3$)$. One year after logging, there were no differences in regeneration density among the studied habitats and the unlogged area $(p>0.3)$ whereas four years after logging, regeneration was denser on log landings $(p<0.05)$. Eight years after logging, the only difference in density was that natural regeneration of trees was scarce in crown gaps ( $p<0.05$; Table S3).

Size class distributions of tree seedlings, saplings, and poles differed among habitats $(p<0.001$; Table S4) and varied with time after logging $(p<0.0001$; Fig. 4). Seedlings $0.5-1.0 \mathrm{~m}$ tall were most abundant one year after logging, whereas small saplings (1-3 $\mathrm{m}$ tall) were more abundant four and eight years after logging.

One year after logging and compared to unlogged forest, pioneer species, a group that includes some commercial pioneer species such as Cedrela odorata, Ceiba petandra and Handroanthus serratifolius (Table S1), were higher in relative density on log landings $(1.9 \pm 0.4 \% ; p<0.0001)$, on secondary roads $(1.6 \pm 0.6 \%$; $p=0.02)$, and on skid trails $(1.7 \pm 0.1 \% ; p=0.04$; Fig. 5 and Table S5). Four and eight years after logging, only secondary roads and log landings differed from unlogged forest in the densities of pioneer tree species $(p<0.0001)$. The densities of non-pioneer
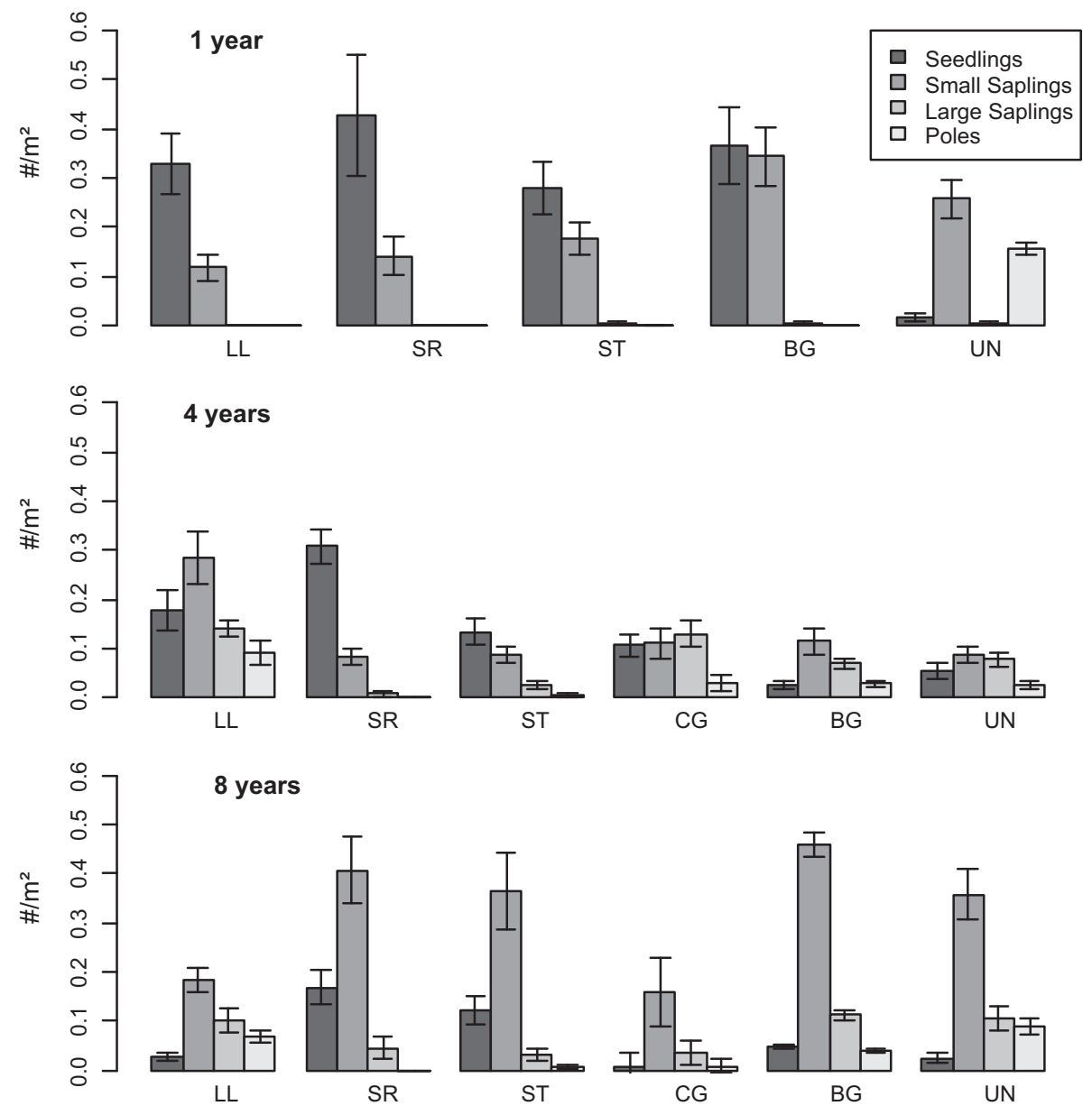

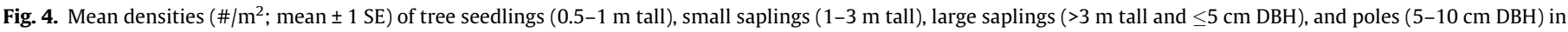
three annual cutting blocks (i.e., APUs). Habitats: $L L=\log$ landing; SR = secondary road; $S T=$ skid trail; $B G=$ bole gap; $C G=$ crown gap; UN = unlogged. 

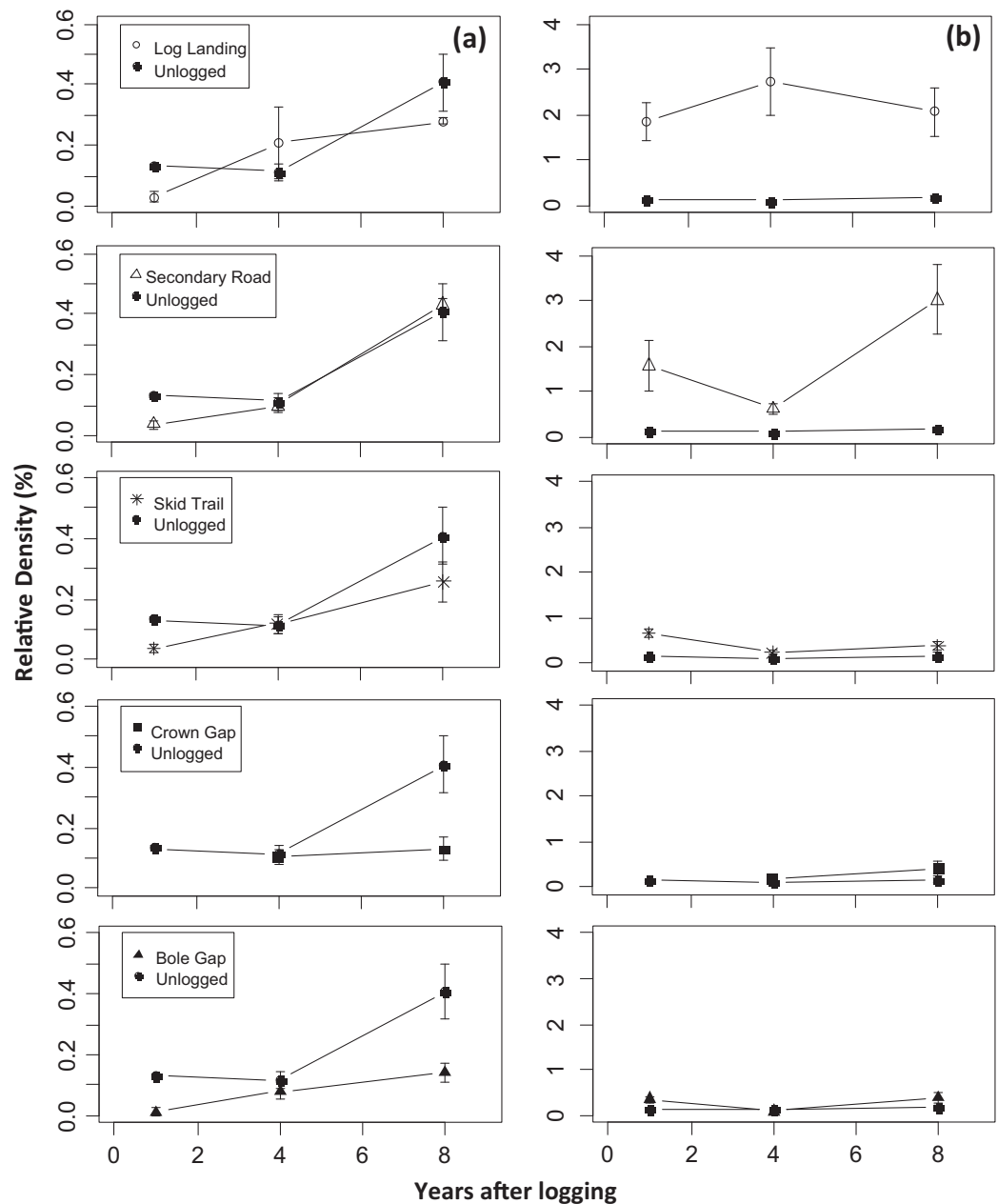

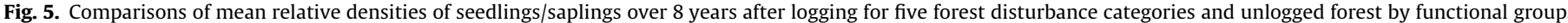
(a): non-pioneer species; (b): bioneer species. Each box includes the comparisons between disturbed habitats and unlogged forest.

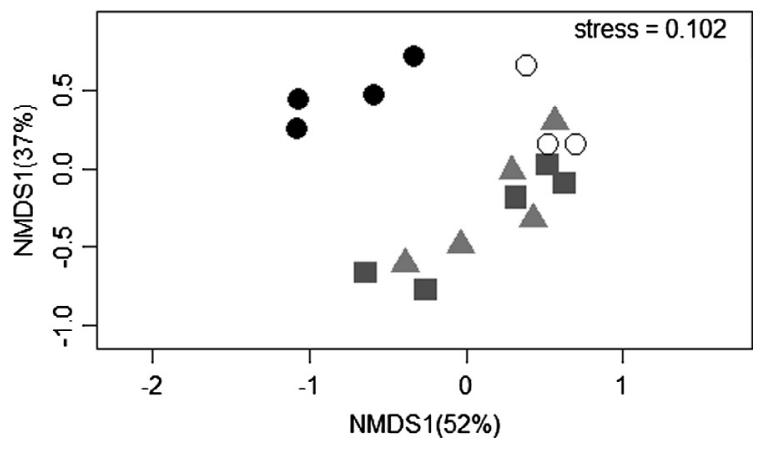

Fig. 6. Non-metric multidimensional scaling (NMDS) ordination of seedlings and saplings of tree species in plots 1, 4, 8 years after logging and unlogged sites (black circle, gray square, gray triangle and white circle respectively). The first NMDS axis explains $52 \%$ of the variation, and the second axis $37 \%$. Stress $=0.11$. (PERMANOVA: 1 year versus 4 years: $F=3.12, p=0.009 ; 1$ year versus 8 years: $F=3.48, p=0.013$; 4 years versus 8 years: $F=0.98, p=0.472 ; 1$ year versus unlogged: $F=4.105$, $\mathrm{p}=0.022 ; 4$ years versus unlogged: $\mathrm{F}=1.83, \mathrm{p}=0.134 ; 8$ years versus unlogged: $\mathrm{F}=1.83, \mathrm{p}=0.125$ ).

species did not differ between logged and undisturbed habitats (Tukey's test: $p>0.2$; Table S6).

The ordination of the 170 species in 51 families (Fig. 6) showed that about $52 \%$ of the variance was explained by the first axis and $37 \%$ by the second (stress $=0.11$ ). . Plots in the one-year post logging APU differed in species composition from those in the four, eightyears post-logging plots and the control area.
Species diversity, as measured by Fisher's alpha (Fig. 7), differed among all habitats one and four years after logging $(p<0.0007)$. One year after logging diversity was highest in the unlogged plots followed by the skid trail plots. Four years after-logging diversity was higher in crown gaps followed by skid trails. After eight years, only secondary roads and log landings were lower in diversity than unlogged sites ( $p<0.001$; Table S7).

\subsection{Environmental conditions}

One year after logging the canopy was more open than in unlogged forest on log landings ( $45.4 \pm \mathrm{SE} 4.5 \%)$, on secondary roads $(26.9 \pm$ SE $3.3 \%)$, and in bole gaps (22.6 \pm SE $4.4 \%)$ but not on skid trails (10.6 $\pm 4.3 \%$; Fig. 8 ). Four and eight years after logging, canopy openness did not exceed $10 \%$ and did not differ among habitats or between logged and unlogged areas (Table S8).

Soil bulk density (Fig. 9) was higher in the top $5 \mathrm{~cm}$ on log landings one and four years after logging than in the unlogged forest $(p<0.0001)$. At $15 \mathrm{~cm}$ and $35 \mathrm{~cm}$, four years after logging, bulk density was also higher on log landings $(p<0.0001)$. By eight years after logging there were no differences in soil bulk density among habitats at any depth ( $p>0.60$; Table S9).

\subsection{Area directly affected by logging}

The areas affected directly by logging operations were $7.0 \%$ in APU 2013, 8.6\% in APU 2010, and 7.5\% in APU 2007 (Table 2). 


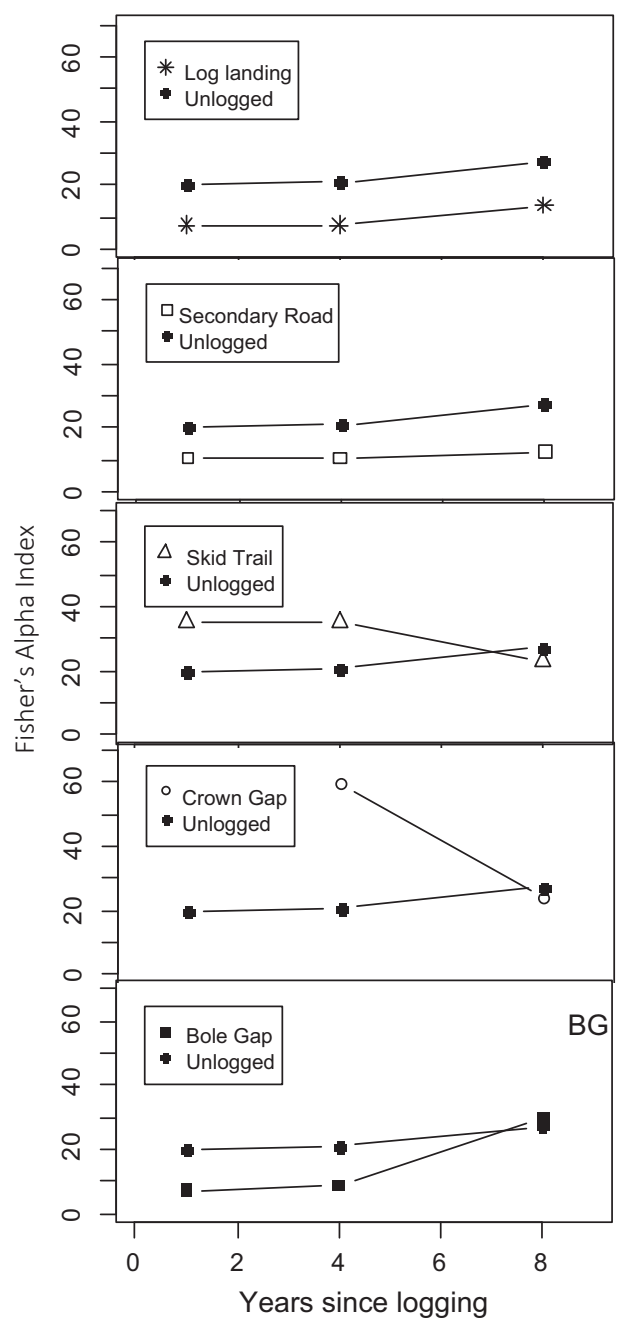

Fig. 7. Changes in Fisher's alpha over 8 years after selective logging in Antimary State Forest. Error bars ( \pm s.e.) are too small to be visible.

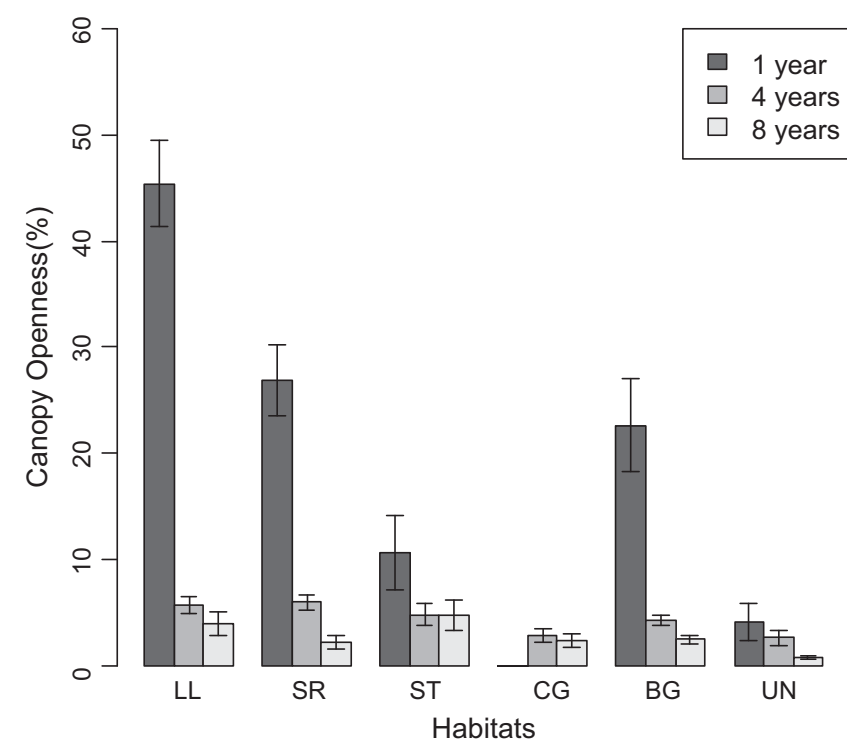

Fig. 8. Canopy openness expressed as $\%$ (mean $\pm 1 \mathrm{SE}$ ) in six habitats one, four, and eight years after logging (habitat codes as in Fig. 4).
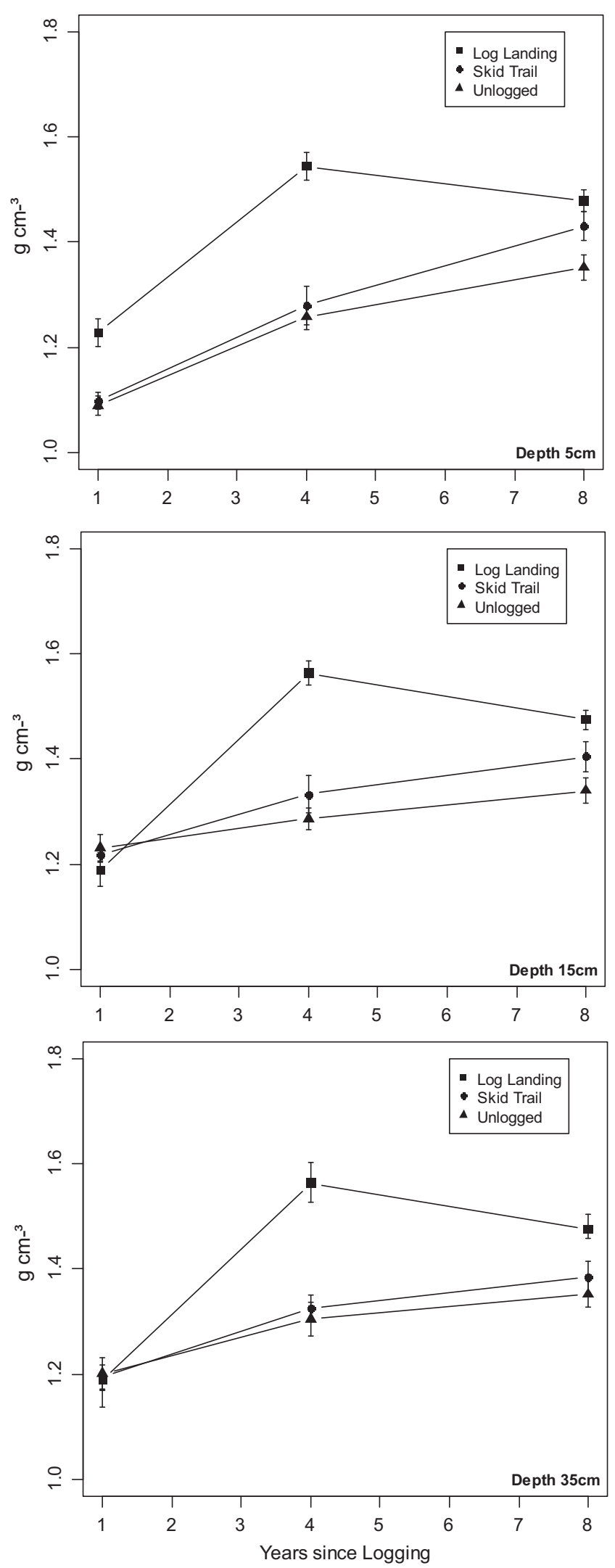

Fig. 9. Soil bulk density at $5 \mathrm{~cm}, 15 \mathrm{~cm}$ and $35 \mathrm{~cm}$ over 8 years after logging in three habitats. 
Table 2

Area disturbed by logging as estimated with LiDAR data in three annual cutting blocks in Antimary State Forest.

\begin{tabular}{|c|c|c|c|c|c|}
\hline Years after logging & Skid trail area (\%) & Secondary road area (\%) & Log landing area (\%) & Felling gap area (\%) & Total area disturbed (\%) \\
\hline 1 year $^{\mathrm{a}}$ & 2.2 & 0.9 & 0.2 & 3.7 & 7 \\
\hline 4 years & 3.2 & 1.6 & 0.3 & 3.5 & 8.6 \\
\hline 8 years $^{\mathrm{b}}$ & 2.9 & 1.3 & 0.2 & 3.0 & 7.5 \\
\hline
\end{tabular}

a LiDAR data 2 years after logging.

b Estimated value using mean values.

The largest proportions of disturbed areas were in felling gaps (3.0-3.7\%), followed by skid trails $(2.2-3.2 \%)$, secondary roads (0.9-1.6\%), and log landings (0.2-0.3\%).

\section{Discussion}

\subsection{Natural regeneration}

The similarities in the densities of regenerating trees in disturbed and undisturbed habitats one year after logging indicates that post-logging recruitment is rapid, as previously reported (e.g., Duah-Gyamfi et al., 2014; Rockwell et al., 2014; Soriano et al., 2012; Karsten et al., 2014; Mostacedo et al., 2009; ToledoAceves et al., 2009; Magnusson et al., 1999). Regeneration was particularly abundant on the exposed mineral soil of log landings, secondary roads and skid trail (Fredericksen and Pariona, 2002). Many of the regenerating trees on disturbed soils were of pioneer species, which was also expected (e.g. Duah-Gyamfi et al., 2014; ToledoAceves et al., 2009; Magnusson et al., 1999; Fredericksen and Mostacedo, 2000; Swaine and Agyeman, 2008), but that group included commercially desirable species of Cedrela, Handroanthus, and Ceiba. The proliferation of pioneers was temporary; it decreased by 3-4 years after logging, by which time non-pioneer species started to increase in abundance (e.g., Duah-Gyamfi et al., 2014). Despite this switch, eight years after logging, relative densities of pioneer species remained high on log landings and on secondary roads presumably in response to the extensive canopy opening (Fredericksen and Mostacedo, 2000; Toledo-Aceves et al., 2009; d'Oliveira and Ribas, 2011). It also appeared that soil disturbance on log landings and secondary roads also favored the regeneration of pioneer tree species (Fredericksen and Pariona, 2002; Denslow, 1995; Dickinson et al., 2000).

The selective logging operations caused the opening of canopy gaps, but many of them were apparently not large enough to promote the establishment (e.g., Toledo-Aceves et al., 2009) and growth of light-demanding species (e.g., Toledo-Aceves et al., 2009; Mostacedo and Fredericksen, 1999). As reported for other forests, tree regeneration density varied with gap size (Mallik et al., 2014) and changed with time since disturbance (d'Oliveira and Ribas, 2011). As we observed in western Brazil, Rivett et al. (2016) found in Guyana that the use of reduced-impact logging (RIL) practices resulted in either a neutral or positive impacts on the densities of seedlings of commercial species, with pioneer species remaining rare. Our study adds that densities of pioneers decline rapidly in most disturbed habitats over time mainly due to the deaths of short-lived pioneer species (e.g. Cecropia sp., Vismia sp. and Sapium marmieri); densities of long-lived commercial pioneer species (e.g. Cedrela odorata, Jacaranda copaia and Handroanthus serratifolius) remained high in disturbed habitats eight years after logging. Although rapid post-logging canopy closure can result in substantial seedling mortality (e.g., Darrigo et al., 2016), the benefits of logging disturbances in our study area were persistent enough to secure commercial tree regeneration.

Logging impacts were not equally distributed across the forest and nor were their effects on species diversity. The less intensively disturbed habitats (i.e., bole and crown gaps) showed early increases in tree species diversity but by eight years post-logging diversity were similar to undisturbed sites; in contrast, the more severely distrubed landings and secondary roads will take longer to recover. The least disturbed areas initially showed the highest diversity of regenerating timber species, but this response varies over time and with the amount of residual competing vegetation.

The autoecology of timber species is diverse and their responses to disturbances are complex (e.g., Karsten et al., 2014). For this reason, it is challenging to find an equilibrium between the minimization of the impacts of logging that are deleterious to some ecosystem functions and species while at the same time promoting the natural regeneration of timber species needed for the longterm economic viability and sustainability of forest management.

\subsection{Canopy openness and soil bulk density}

Canopy closure after logging was rapid; by four years post- logging no differences were apparent between disturbed and undisturbed sites. Duah-Gyamfi et al. (2014) in Ghana found a similar result in a heavily logged forest (volume extracted around $53 \mathrm{~m}^{3}$. $\mathrm{ha}^{-1}$ ), where the canopy closure occurred three years after logging. It is important to mention that log landings in this study (400-500 $\mathrm{m}^{2}$ ) were smaller than those reported by other studies in the Amazon (e.g., $800 \mathrm{~m}^{2}$; d'Oliveira and Braz, 2006) and in Belize (1200 $\mathrm{m}^{2}$; Arevalo et al., 2016).

Soil bulk density on log landings and secondary roads recovered to unlogged forest values between the fourth to the eighth year post-logging. This finding is similar to the reports from another study in the Brazilian Amazon (Darrigo et al., 2016) but differs markedly from what was found in in a heavily logged forest in Malaysia where even 20 years after logging, soil bulk density was still higher on landings (Hattori et al., 2013). Our result might be an effect of the low logging intensity and the use of small trucks (10-ton) for log transport. In any event, it is encouraging that the impacts of logging operations on soil physical characteristics do not persist long enough to prevent natural regeneration.

\subsection{Area directly affected by logging}

The proportion of the ASF forest directly affected by selective logging (7.0-8.6\%) was similar to the values reported for other areas subjected to low-intensity reduced-impact logging (RIL) by Asner et al. (2004) and Pereira Jr. et al. (2002), in the Brazilian Amazon (5.8 $\pm 1.9 \%$ and $7.9 \%$, respectively), and Arevalo et al. (2016) in Belize (7\%). As in those studies, about two thirds of the damaged forest was in felling gaps. In contrast, Jackson et al. (2002) found $25 \%$ of the ground surface was disturbed by logging in Bolivia in a site where selective logging was carried out with a very different approach to RIL that involved opening of parallel skid trails at $150 \mathrm{~m}$ intervals that are intended to remain part of the permanent infrastructure.

Although we are confident in our use of LiDAR data to assess the structural impacts of logging, we recognize that in the time between logging and LiDAR data acquisition, vegetation regrowth can obscure the signals of disturbance. We agree with the recom- 
mendation of Ellis et al. (2016) that for logging damage assessments, LiDAR data should be collected within 2 years of the harvest.

Based on the impacts we observed, logging in ASF complied with the criteria established by Brazilian forest laws. For example, Normative Instruction $\mathrm{N}^{\circ} 04$ recommends that log landings cover $<0.75 \%$ (MMA, 2002) of management areas whereas in our study they only covered $0.2 \%$. This finding suggests that new landings could be opened when the forest is next harvested, which would protect the abundant regeneration of commercial species on the old landings.

\section{Conclusion}

The impact of logging disturbances on tree regeneration varied with disturbance intensity and size. The diversity of natural regeneration was highest where disturbances were intermediate in intensity whereas pioneer tree species proliferated in the more heavily disturbed areas. The observed changes in tree seedling density and floristic composition, soil physical conditions, and canopy openness due to logging were all slight, and mostly recovered to undisturbed forest conditions within eight years after the harvests. The higher density of commercial pioneer timber species in more heavily disturbed habitats observed in this and in other studies suggests that some of these habitats should be considered as regeneration areas to improve timber volume stocks for future harvests. The results showed that the logging system evaluated is sustainable at least in regards to the natural regeneration of commercial tree species.

\section{Acknowledgements}

We are grateful to Embrapa staff especially Airton Farias, Aldeci Oliveira, Fernanda Fonseca and Robert Thompson Morais. The Embrapa Soil Laboratory, Dr. Falberni Costa, Dr. Valdomiro Catani and Pedro Raimundo R. de Araújo. Dalcineude S. de Araújo, Marcos André and Manoel from Antimary State Forest. Dr. Fabricio Baccaro from UFAM and Dr. Michal Kowalewski from University of Florida for useful contributions with multivariate analysis. The Project was funded by CAPES - Coordination for the Improvement of Higher Education Personnel, Ministry of Education of Brazil (3172/2013 and AUXPE 459/2013) and CNPq - National Council for Scientific and Technological Development, of the Ministry of Science, Technology and Innovation of Brazil (462191/2014-1). The doctorate fellowship in Brazil sponsored by CAPES and sandwich period at University of Florida sponsored by the CNPq (grant n. 204700/2014-0).

\section{Appendix A. Supplementary material}

Supplementary data associated with this article can be found, in the online version, at http://dx.doi.org/10.1016/j.foreco.2017.02. 049.

\section{References}

Arevalo, B., Valladarez, J., Muschamp, S., Kay, E., Finkral, A., Roopsind, A., Putz, F.E. 2016. Effects of reduced-impact selective logging on palm regeneration in Belize. For. Ecol. Manage. 369, 155-160.

Asner, G.P., Keller, M., Pereira, R., Zweede, J.C., Silva, J.N.M., 2004. Canopy damage and recovery after selective logging in Amazonia: field and satellite studies. Ecol. Appl. 14, 280-298.

Blake, G.R., Hartge, K.H., 1986. Bulk density. In: Klute, A. (Ed.), Methods of Soil Analysis: Physical and Mineralogical Methods. Part 1. American Society of Agronomy, Madison, pp. 363-375.

de Carvalho, A.L., Nelson, B.W., Bianchini, M.C., Plagnol, D., Kuplich, T.M., Daly, D.C., 2013. Bamboo-dominated forests of the Southwest Amazon: detection, spatia extent, life cycle length and flowering waves. PLoS ONE 8 (1), e54852.
Colwell, R.K., 2013. EstimateS: Statistical estimation of species richness and shared species from samples. Version 9. User's Guide and application available online at <http://purl.oclc.org/estimates>.

CONAMA - National Environmental Council 2009. Resolução no 406/2009. <http:// www.mma.gov.br/port/conama/legiabre.cfm?codlegi=597>.

Darrigo, M.A., Venticinque, E.M., Santos, F.A.M., 2016. Effects of reduced impact logging on the forest regeneration in the central Amazonia. For. Ecol. Manage. 360, 52-59.

Denslow, J.S., 1995. Disturbance and diversity in tropical rain forests: the density effect. Ecol. Appl. 5, 962-968. http://dx.doi.org/10.2307/2269347.

Dickinson, M.B, Whigham, D.F, Hermann, S.M., 2000. Tree regeneration in felling and natural treefall disturbances in a semideciduous tropical forest in Mexico, vol. 134 , pp. 137-151.

d'Oliveira, M.V.N., Braz, E.M., 2006. Estudo da dinâmica da floresta manejada no projeto de manejo florestal comunitário do PC Peixoto na Amazônia Ocidental. Acta Amazonica 36, 177-182.

d'Oliveira, M.V.N., Ribas, L.A., 2011. Forest regeneration in artificial gaps twelve years after canopy opening in Acre State Western Amazon. For. Ecol. Manage. 261, 1722-1731.

d'Oliveira, M.V.N., Reutebuch, S.E., McGaughey, R.J., Andersen, H., 2012. Estimating forest biomass and identifying low-intensity logging areas using airborne scanning lidar in Antimary State Forest, Acre State, Western Brazilian Amazon. Remote Sens. Environ. 124, 479-491.

d'Oliveira, M.V.N., Guarino, E.de S., Oliveira, L.C., Ribas, L.A., Acuña, M.H.A., 2013. Can forest management be sustainable in a bamboo dominated forest? A 12 year study of forest dynamics in western Amazon. For. Ecol. Manage. 310, 672679.

Duah-Gyamfi, A., Swaine, E.K., Adam, K.a., Pinard, M.a., Swaine, M.D., 2014. Can harvesting for timber in tropical forest enhance timber tree regeneration? For. Ecol. Manage. 314, 26-37.

Ellis, P., Griscom, B., Walker, W., Gonçalves, F., Cormier, T., 2016. Mapping selective logging impacts in Borneo with GPS and airborne LiDAR. For. Ecol. Manage. 365, 184-196.

Elliott, K.J., Knoepp, J.D., 2005. The effects of three regeneration harvest methods on plant diversity and soil characteristics in the southern Appalachians. For. Ecol. Manage. 211, 296-317.

Figueiredo, E.O., 2007. Manejo de precisão em florestas tropicais: modelo digital de exploração florestal. Embrapa Acre, Rio Branco, AC.

Fredericksen, T.S., Mostacedo, B., 2000. Regeneration of timber species following selection logging in a Bolivian tropical dry forest. For. Ecol. Manage. 131, 47-55.

Fredericksen, T.S., Pariona, W., 2002. Effect of skidder disturbance on commercial tree regeneration in logging gaps in a Bolivian tropical forest. For. Ecol. Manage. $171,223-230$

FUNTAC, 1989. Estrutura do plano de manejo de uso múltiplo da floresta Estadual do Antimary. Rio Branco, Acre. 103 pp.

Hattori, D., Kenzo, T., Irino, K.O., Kendawang, J.J., Ninomiya, I., Sakurai, K., 2013. Effects of soil compaction on the growth and mortality of planted dipterocarp seedlings in a logged-over tropical rainforest in Sarawak, Malaysia. For. Ecol. Manage. 310, 770-776.

Jackson, S.M., Fredericksen, T.S., Malcolm, J.R., 2002. Area disturbed and residual stand damage following logging in a Bolivian tropical forest. For. Ecol. Manage. $166,271-283$

Karsten, R.J., Meilby, H., Larsen, J., 2014. Regeneration and management of lesser known timber species in the Peruvian Amazon following disturbance by logging. For. Ecol. Manage. 327, 76-85.

Magnusson, W.E., Odilon, Lima, O.P., Reis, F.P., Higuchi, N., Ramos, J.F., 1999. Logging activity and tree regeneration in an Amazonian forest. For. Ecol. Manage. 113, 67-74.

Magurran, A.E., 2004. Measuring Biological Diversity. Blackwell Science, Oxford. 256p..

Mallik, A.U., Kreutzweiser, D.P., Spalvieri, C.M., 2014. Forest regeneration in gaps seven years after partial harvesting in riparian buffers of boreal mixedwood streams. For. Ecol. Manage. 312, 117-128.

McGaughey, R.J., 2010. FUSION/LDV: Software for LIDAR data analysis and visualization. United States Department of Agriculture, Forest Service, Pacific Northwest Research Station, 154 pp.

McNabb, K.L., Miller, M.S., Lockaby, B.G., Stokes, B.J., Clawson, R.G., Stanturf, J.A., Silva, J.N.M., 1997. Selection harvests in Amazonian rainforests: long-term impacts on soil properties. For. Ecol. Manage. 93, 153-160.

MMA, 2002. Instrução Normativa $N^{\circ} 4$, de 4 de Março de 2002.

Mostacedo, B., Fredericksen, T.S., 1999. Regeneration status of important tropical forest tree species in Bolivia: assessment and recommendations. For. Ecol Manage. 124, 263-273.

Mostacedo, B., Putz, F.E., Fredericksen, T.S., Villca, A., Palacios, T., 2009. Contributions of root and stump sprouts to natural regeneration of a logged tropical dry forest in Bolivia. For. Ecol. Manage. 258, 978-985.

Nelson, B.W., 1994. Natural forest disturbance and change in the Brazilian Amazon. Remote Sens. Rev. 10, 105-125.

Oksanen, J., Blanchet, F.G., Kindt, R., Legendre, P., Minchin, P.R., O'Hara, R.B., et al., 2013. Vegan: Community Ecology Package. R package version 2.0-8. <http:// CRAN.R-project.org/package=vegan $>$.

Pereira, R., Zweede, J., Asner, G., Keller, M., 2002. Forest canopy damage and recovery in reduced-impact and conventional selective logging in eastern Para, Brazil. For. Ecol. Manage. 168, 77-89.

Pinard, M.A., Putz, F.E., Tay, J., Sullivan, T.E., 1995. Creating timber harvesting guidelines for a reduced-impact logging project in Malaysia. J. Forest. 93, 41-45. 
Putz, F.E., Blate, G.M., Redford, K.H., Fimbel, R., Robinson, J.G., 2001. Biodiversity conservation in the context of tropical forest management. Conserv. Biol. 15, 720.

Rivett, S.L., Bicknell, J.E., Davies, Z.G., 2016. Effect of reduced-impact logging on seedling recruitment in a neotropical forest. For. Ecol. Manage. 367, 71-79.

Rockwell, C.A., Kainer, K.A., d’Oliveira, M.V.N., Staudhammer, C.L., Baraloto, C., 2014. Logging in bamboo-dominated forests in southwestern Amazonia: Caveats and opportunities for smallholder forest management. For. Ecol. Manage. 315, 202210.

Salimon, C.I., Putz, F.E., Menezes-Filho, L., Anderson, A., Silveira, M., Foster, B.I., Oliveira, L.C., 2011. Estimating state-wide biomass carbon stocks for a REDD plan in Acre, Brazil. For. Ecol. Manage. 262, 555-560.

Soriano, M., Kainer, K.A., Staudhammer, C.L., Soriano, E., 2012. Implementing multiple forest management in Brazil nut-rich community forests: effects of logging on natural regeneration and forest disturbance. For. Ecol. Manage. 268, 92-102.

Swaine, M.D., Agyeman, V.K., 2008. Enhanced tree recruitment following logging in two forest reserves in Ghana. Biotropica 40, 370-374.
Swaine, M.D., Withimore, T.C., 1988. On the definition of ecological species groups in Tropical rain forests. Vegetatio 75, 81-86.

TerSteege, H., Boot, R.H., Brouwer, L., Hammond, D., Van Der Hout, P., Jetten, V.G., Khan, Z., Polak, A.M., Raaimakers, D., Zagt, R., 1995. Basic and applied research for sound rain forest management in Guyana. Ecol. Appl. 5, 904-910.

Toledo-Aceves, T., Purata-Velarde, S., Peters, C.M., 2009. Regeneration of commercial tree species in a logged forest in the Selva Maya, Mexico. For. Ecol. Manage. 258, 2481-2489.

Vieira, G., 1995. Dynamics of the remaining plant population in gaps after logging in the Amazon. Confer. Forest. Forest Prod. Res., 54-67

Wang, S., 2004. One hundred faces of sustainable forest management. Forest Policy Econ. 6, 205-213.

Yamamoto, S., 2000. Forest gap dynamics and tree regeneration. J. Forest Res. 5, 223-229.

Zimmerman, B., Kormos, C., 2012. Prospects for sustainable logging in tropical forests. Bioscience 62, 479-487. 